\title{
Developing Subject Specific Pedagogy (SSP) of Problem Based Learning Model in Laboratory to Improve Problem Solving Ability and Motivation of Students of Senior High School
}

\author{
Godelfridus H. Lamanepa \\ Physics Education Department \\ Unwira Kupang \\ Kupang, Indonesia \\ godelfriduslamanepa@gmail.com
}

\begin{abstract}
This study aims to: (1) produce a physics subject specific pedagogy (SSP) of PBL model in laboratory activity appropriate to be in used physics learning of senior high school, (2) determine the effectiveness of the physics SSP of PBL model in laboratory activity to improve problem solving ability of students of senior high school, and (3) determine the effectiveness of the physics SSP of PBL model in laboratory activity to improve learning motivation of students of senior high school.The subjects of the study were grade $X_{3}$ and $X_{5}$ students of SMA Giovani Kupang.The data analysis technique using a quantitative descriptive and manova test with a significance level of 5\%.The results are as follows: (1) The developed physics SSP of PBL model in laboratory activity consisting of a lesson plans, handout, students worksheets, and assesment of problem solving ability and motivation learning questionnaire is declared fit for physics teaching in SMA Giovani Kupang. (2) The developed physics SSP of PBL model in laboratory activity is effective to improve the problem solving ability of the students of SMA Giovani Kupang. (3) The developed physics SSP of PBL model in laboratory activity is effective to improve learning motivation of the students of SMA Giovani Kupang.
\end{abstract}

Keywords-Physics SSP, PBL, Problem Solving Ability, Learning Motivation

\section{INTRODUCTION}

A study will be done and achieved good results as expected if done with careful planning process of learning. Learning plan in question is a plan that includes a concept of learning to make learners active role and be able to explore the potential that exists in itself, so that learners are able to develop certain abilities such as problem solving skills, decision-making, analyzing data, thinking logical and systematic. To create the physics study results are good, there are three main components to consider including planning, implementation and assessment. Planning is a very important factor in achieving the learning objectives, without careful planning would be difficult to achieve learning objectives. Learning plan can be implemented in the form of subjectspecific learning tools or pedagogy (SSP).
Subject specific pedagogy (SSP) represents the current Efforts to integrate the learning of content with the learning of pedagogy. A goal that has eluded Attracted teacher and educator for more than a century. Subject specific pedagogy (SSP) or later known Pedagogical Content Knowledge (PCK) is a concept that has developed over time and sometimes is regarded by teachers as part of the "common sense knowledge about teaching", [1].

Pedagogical knowledge is deep knowledge about the processes and practices of teaching and learning, encompassing educational purposes, goals, values, strategies, and more. This is a generic form of knowledge that applies to student learning, classroom management, instructional planning and implementation, and student assessmen [2]t. It includes knowledge about techniques or methods used in the classroom, the nature of the learners' needs and preferences, and strategies for assessing student understanding. A teacher with deep pedagogical knowledge understands how students construct knowledge and acquire skills in differentiated ways, as well as how they develop habits of mind and dispositions toward learning. As such, pedagogical knowledge requires an understanding of cognitive, social, and developmental theories of learning and how they apply to students in the classroom.

Knowledge of subject matter and general pedagogical strategies,though necessary, was not sufficient for capturing the knowledge of good teachers[3]. To characterize the complex ways in which teachers think about how particular content should be taught, he argued for "pedagogical content knowledge" as the content knowledge that deals with the teaching process, including "the ways of representing and formulating the subject that make it comprehensible to others". For teachers to be successful,they would have to confront both issues (content and pedagogy) simultaneously by embodying "the aspects of content most germane to its teachability". 
PBL models selected as a reference in planning the learning process. Problem-based learning: An instructional method that initiates students' learning by creating a need to solve an authentic problem. During the problem solving process, students construct content knowledge and develop problem-solving skills as well as self-directed learning skills while working toward a solution to the problem, [4]. In PBL, students learn by solving problems and reflecting on their experiences, [5]. Problem-based learning is an approach to learning where the curricula are designed with the problem scenarios as central to student learning in each component of the curriculum (modules/units), [6]. PBL is well suited to helping students become active learners because it situates in real-world problems and makes students responsible for their learning.

Problem solving as "cognitive processing directed at transforming a given situation into a goal situation when no obvious method of solution is available"[7], and problem solving is the most important manifestation of human thinking, the goal of solving problems is finding a solution [8].

The observation of the implementation of learning at Senior high school Giovani Kupang shows that the implication of learning, teachers rarely presents real problems related to the concept of physics to be solved together in the classroom. Learning is directed more towards completion of physics problems with less attention to the process of investigation or practicum activities. Learning activities are certainly not an impact on the process of solving problems either by individuals or by study groups.

The essence of the subject specific pedagogy (SSP) of physics is how to teach the subject of certain physics lessons in the design of learning to pay attention to the characteristics of learners, and the characteristics of teaching materials physics. Subject specific pedagogy of physics can be arranged well if teacher have good pedagogical knowledge knowledge also. Subject specific pedagogy physics is a container for pouring ideas, steps, and arrangements how physics learning will be implemented effectively and educate. Subject specific pedagogy of physics developed, among others, lesson plan, Handout, worksheet and instuments of problem solving test and motivation questionnaire. Worksheet is a kind of printed instructional material that is prepared and frequently used by teachers in order to helpstudents to gain knowledge, skills and values by providing helpful comments about the course objectives and enabling students to engage in active learning and learning-by-doing in and out of the school, [9].

Motivation has been viewed as a key factor influencing learning outcomes. High learning achievements often are attributed to high motivation in the student and a learning that nurtures high motivation. Efforts that can be made to improve the motivation of learners is to create the basic conditions that affect motivation. Defined from current cognitive perpective, therefore, motivation is the process in which "goal-directed activity is instigated and sustained, [10].

The most important of the basic motivational conditions are (1) appropriate teacher behaviours and good relationship with the students, (2) a pleasant and suppotive classroom atmospher, and (3) a cohesive learner group with appopriate groups norms [11]. Teachers have a very important role in improving motivation learners learners. Teachers should always try to develop motivation learners in the classroom. The purpose of motivation given to the learners is to motivate the learners to arise desire and hope to learn so as to achieve educational goals as expected.

\section{METHOD}

This study included in the research development with 4D development model. The 4D model consists of four stages, including (1) define, (2) design, (3) develop, and (4) disseminate, [12].

The subjects of the study were grade $\mathrm{X}_{3}$ and $\mathrm{X}_{5}$ students of Senior High Shool Giovani Kupang in the second semester of the school year of 2015/2016 with the subject of a static fluid.

The data analysis technique which was used was quantitative descriptive and manova test with a significance level of 5\%. Following four instruments were used in the study: 1) validation sheet of SSP, 2) problem solving ability test, 3) learning motivation questionnaire, 4) learning observation sheet.

\section{RESULTS AND DISCUSSION}

\section{Assessment Instrument Validation Results}

This validation aims to validate the format/sheet of the instrument used to validate the instrument to be used. Validated validation instrument formats include: (1) validation of the SSP, (2) validation questionnaire sheets, (3) learning observation sheets and (4) validation of problem-solving validation papers. Validation results of each instrument validation format above calculated the content validity of the content (content validity ratio) using Lawshe equation.

The result of calculation of instrument sheet validation as follows.

\section{TABLE I. RESULT OF PRODUC VALIDATION}

\begin{tabular}{|c|c|c|c|}
\hline Product & CVR & Item & Category \\
\hline \multirow{3}{*}{ Leson Plan } & 0,33 & 2 & Poor \\
\cline { 2 - 4 } & 0,67 & 18 & Good \\
\cline { 2 - 4 } & 1,00 & 5 & Very good \\
\hline
\end{tabular}




\begin{tabular}{|l|c|c|c|}
\hline \multirow{3}{*}{ Handout } & 0,67 & 9 & Good \\
\cline { 2 - 4 } & 1,00 & 11 & Very good \\
\hline \multirow{3}{*}{ Worksheet } & 0,67 & 9 & Good \\
\cline { 2 - 4 } & 1,00 & 11 & Very good \\
\hline \multirow{2}{*}{ Quetionnaire } & 0,67 & 6 & Good \\
\cline { 2 - 4 } & 1,00 & 7 & Very good \\
\hline \multirow{2}{*}{ Test } & 0,67 & 5 & Good \\
\cline { 2 - 4 } & 1,00 & 8 & Very good \\
\hline \multirow{2}{*}{ Observation } & 0,67 & 9 & Good \\
\cline { 2 - 4 } & 1,00 & 9 & Very good \\
\hline
\end{tabular}

This analysis technique is referred to the calculation of the content validity coefficient (content validity ratio), [13]. Item with poor categories are not used or discarded while items that are in good category and are very good used for futher research.

The feasibility assessment of products developed on a scale of five is shown as follows.

\section{TABLE II. RESULT OF PRODUCT ASSESSMENT}

\begin{tabular}{|l|c|}
\hline \multicolumn{1}{|c|}{ Produk } & Kategori \\
\hline Lesson plan & Very good \\
\hline Handout & Good \\
\hline Worksheet & Very good \\
\hline Questionnaire & Good \\
\hline Test & Very good \\
\hline
\end{tabular}

Product assessment is done by experts, teachers and peers. Each product consists of assessment items. In general the products develop are in good category and vey good.

\section{2. $\quad$ Limited Test Result}

Learning outcomes are obtained from the observation sheets of instructional implementation as assessed by two observers. The results of the implementation of learning as follows.

TABLE III. RESULT OF LEARNING IMPLEMENTATION

\begin{tabular}{|l|c|c|}
\hline \multirow{2}{*}{ Explanation } & \multicolumn{2}{|c|}{ Assessment } \\
\cline { 2 - 3 } & Learning Process 1 & Learning Process 2 \\
\hline $\begin{array}{l}\text { Learning achievement } \\
(\%)\end{array}$ & 78 & 86 \\
\hline $\begin{array}{l}\text { Percentage of } \\
\text { agreement (\%) }\end{array}$ & 93 & 97 \\
\hline
\end{tabular}

The results of learning implementation analysis based on the percentage of learning achievement in learning process 1 and 2 respectively assessed "good" and "very good".

The result of the test of the problem solving ability test instrument is obtained as follows.

TABLE IV. TEST INSTRUMENT VALIDITY OF PROBLEM SOLVING ABILITIES

\begin{tabular}{|c|c|c|}
\hline \multirow{2}{*}{ No } & Interpretation & \multirow{2}{*}{ Explanation } \\
\cline { 2 - 3 } & $\begin{array}{c}\text { Corrected Item-Total } \\
\text { Correlation value }\end{array}$ \\
\hline 1 & 0,870 & Item valid \\
\hline 2 & 0,517 & Item valid \\
\hline 3 & 0,540 & Item valid \\
\hline 4 & 0,872 & Item valid \\
\hline 5 & 0,552 & Item valid \\
\hline 6 & 0,413 & Item valid \\
\hline 7 & 0,670 & Item valid \\
\hline 8 & 0,670 & Reliable \\
\hline \multirow{2}{*}{} & Instrument reliability & \\
\cline { 2 - 3 } & 0,868 & \\
\hline
\end{tabular}

The test results of item validity and reliability of questionnaire instruments are presented as follows.

TABLE V. TEST VALIDITY QUESTIONAIRE

\begin{tabular}{|c|l|l|c|}
\hline No & \multicolumn{2}{|c|}{ Interpretation } & Result \\
\hline 1 & $\begin{array}{l}\text { Corrected Item- } \\
\text { Total Correlation } \\
\text { value }\end{array}$ & Item valid & 31 item \\
\cline { 3 - 4 } & $\begin{array}{l}\text { Cronbach's } \\
\text { Alpha value }\end{array}$ & $\begin{array}{l}\text { Reliability of } \\
\text { questionnaire }\end{array}$ & 4 item \\
\hline
\end{tabular}

Item validity testing and instrument reliability are used for interpretation of Corrected Item-Total Correlation and Cronbach's Alpha values. The test results show that 31 items are valid.

\section{Field Testing Result}

The results of the analysis of the implementation of field test learning are obtained as follows:

TABLE VI. RESULT OF LEARNING IMPLEMENTATION

\begin{tabular}{|c|c|c|}
\hline $\begin{array}{c}\text { Learning } \\
\text { Process }\end{array}$ & Learning Process (\%) & Kategori \\
\hline 1 & 72 & Good \\
\hline 2 & 77 & Very good \\
\hline
\end{tabular}




\begin{tabular}{|l|c|c|}
\hline 3 & 81 & Very good \\
\hline 4 & 88 & Very good \\
\hline
\end{tabular}

Based on Table vi, it is stated that generally the result of experimental class learning implementation on learning in field test is considered "very good".

The result of initial learning motivation of experimental class and control class is shown as follow:

\section{TABLE VII. MOTIVATION BEFORE LEARNING}

\begin{tabular}{|l|c|c|}
\hline Category & $\begin{array}{c}\text { Motivation of } \\
\text { Experiment Class } \\
(\boldsymbol{\%})\end{array}$ & $\begin{array}{c}\text { Motivation of } \\
\text { Control Class } \\
(\mathbf{\%})\end{array}$ \\
\hline Very good & 3 & 3 \\
\hline Good & 9 & 16 \\
\hline Acceptable & 16 & 28 \\
\hline Poor & 56 & 37 \\
\hline Very Poor & 16 & 16 \\
\hline
\end{tabular}

The result of final experimental learning motivation and control class is shown as follows:

TABLE VIII. MOTIVATION AFTER LEARNING

\begin{tabular}{|l|c|c|}
\hline Category & $\begin{array}{c}\text { Motivation of } \\
\text { Experiment Class } \\
(\boldsymbol{\%})\end{array}$ & $\begin{array}{c}\text { Motivation of } \\
\text { Control Class } \\
(\boldsymbol{\%})\end{array}$ \\
\hline Very good & 19 & 9 \\
\hline Good & 59 & 60 \\
\hline Acceptable & 13 & 22 \\
\hline Poor & 6 & 6 \\
\hline Very Poor & 3 & 3 \\
\hline
\end{tabular}

Based on Table vii and table viii shows that there is an increase in learning motivation of learners after learning using PBL model. Results are in accordance with the opinion of [14] PBL is a motivational, challenging and fun learning model that results from the work process for understanding or problem solving.

Results Analysis of problem solving abilities by learners in control and experimental classes is presented as follows.

TABLE IX. RESULT OF PROBLEM SOLVING ABILITY

\begin{tabular}{|l|c|c|c|c|}
\hline Information & \multicolumn{4}{|c|}{ Problem Solving ability } \\
\hline \multirow{3}{*}{} & \multicolumn{2}{|c|}{ Control class } & \multicolumn{2}{c|}{ Experiment class } \\
\cline { 2 - 5 } & Pre & Post & Pre & Post \\
test & test & test & test \\
\hline Highest score & 76,7 & 90,0 & 76,7 & 91,7 \\
\hline Lowest score & 33,3 & 63,3 & 40,0 & 71,7 \\
\hline Average & 59,4 & 77,6 & 59,7 & 83,3 \\
\hline
\end{tabular}

\begin{tabular}{|l|l|l|}
\hline Gain & 0,45 & 0,58 \\
\hline
\end{tabular}

Based on Table ix, it is known that the average gain in the experimental class is higher than the control class. The problem-based learning model turns the student from passive information recipient to active, free selflearner and problem solver, and it slides the emphasis of educational programs from teaching to learning. This model enables the student to learn new knowledge by facing him/her the problems to be solved, instead of burdened contents, [15].

Multivariate normality test results of problem solving and learning motivation are presented as follows.

TABLE X. NORMALITY GAIN TEST RESULTS SCORE PROBLEM SOLVING AND MOTIVATION LEARNING

\begin{tabular}{|l|c|c|c|c|}
\hline \multirow{2}{*}{ Variable } & \multirow{2}{*}{ Class } & \multicolumn{2}{|c|}{$\begin{array}{c}\text { Kolmogorov- } \\
\text { Smirnov }\end{array}$} & \multirow{2}{*}{ Distribution } \\
\cline { 3 - 4 } & & $\boldsymbol{d f}$ & Sig. & \\
\hline $\begin{array}{l}\text { Problem } \\
\text { solving }\end{array}$ & Control & 32 & 0,200 & Normal \\
\cline { 2 - 5 } & Experiment & 32 & 0,200 & Normal \\
\hline Learning \\
motivation
\end{tabular}

Table 11 shows the Kolmogorov-Smirnov test results that show the sig value. $0.200>0.05$ for each class. With these results, it was concluded that the gain score of physics problem solving ability and learning motivation in the control class and experiment class is normally distributed.

The homogeneity test of variance is presented in Table as follows.

TABLE XI. VARIANCE HOMOGENEITY TEST RESULT

\begin{tabular}{|l|c|c|c|}
\hline Variable & F & Sig & Varians \\
\hline Problem solving & 2,053 & 0,157 & Homogen \\
\hline Learing Motivation & 0,614 & 0,436 & Homogen \\
\hline
\end{tabular}

Table xi shows that the sig value $>0.05$. Thus $\mathrm{H} 0$ is accepted. Furthermore it can be concluded that problem solving and learning motivation come from the same variance.

The assumption that must be fulfilled in manova is the similarity of inter-group covariance matrix to the dependent variable. To test this condition can use Box's M test on SPSS 16.0 for windows. The homogeneity test of variance/ covariance matrix is presented as follows. 
TABLE XII. COVARIANCE MATRIX TEST RESULTS

\begin{tabular}{|l|r|}
\hline Box's M test & 2,849 \\
F & 0,917 \\
df1 & 3 \\
df2 & $6,919 \mathrm{E} 5$ \\
sig. & 0,432 \\
\hline
\end{tabular}

Box's $M$ test result shows sig value $>0,05$. It can be concluded that the variant / covariance matrix is derived from the same dependent variable.

After the prerequisite test is fulfilled resumes manova test. The results of the manova test are presented as follows:

TABLE XIII. MANOVA TEST RESULT

\begin{tabular}{|c|c|}
\hline Effect & Sig \\
\hline Pillai's Trace & 0,000 \\
Wilk's Lambda & 0,000 \\
Hotelling's Trace & 0,000 \\
Roy's Largest & 0,000 \\
\hline
\end{tabular}

Based on Table xiii it is known that the sig values of Pillai's Trace, Wilks' Lambda, Hotelling's Trace, and Roy's Largest Root are less than 0.05 (sig <0.05). Because the value of sig $<0,05$ then hypothesis rejected. It can be concluded that there is difference of gain score of problem solving ability and learning motivation between experiment class and control class. Differences between these two variables can be seen in Table test results of between-subjects effects.

\section{TABLE XIV. TEST OF BETWEEN-SUBJECTS EFFECTS}

\begin{tabular}{|l|c|c|}
\hline \multicolumn{1}{|c|}{ Dependent Variable } & F & Sig \\
\hline Problem Solving & 31,109 & 0,000 \\
\hline Learning Motivation & 0,959 & 0,044 \\
\hline
\end{tabular}

Based on the results of the Test of Between-Subjects Effects in Table 21 it is known that the learning motivation between the control and experiment classes has a significance value of less than 0.05 ( $\mathrm{sig}<0.05)$ so that $\mathrm{H} 0$ is rejected. This means that there is a significant difference in the gain of learning motivation score between the experimental class and the control class. In addition, it is also known that the problem-solving ability relationship between classes has a sig value smaller than 0.05 ( $\mathrm{sig}<0.05$ ) so that $\mathrm{H} 0$ is rejected. This means that there is a gain difference in the scores of problemsolving skills between the experimental class and the control class.
Based on the results of the manova test it can be said that there are significant differences in the variables of learning motivation and the problem solving ability of learners between the control class and the experimental class.

\section{CONCLUSION}

Based on the results of data analysis research can be concluded the result of product development subject specific pedagogy physics are as follows; (1) The developed physics SSP of PBL model in laboratory activity consisting of a lesson plans, handout, students worksheets, and assesment of problem solving ability and motivation learning questionnaire is declared fit for physics teaching in senior high school Giovani Kupang. (2) The developed physics SSP of PBL model in laboratory activity is effective to improve the problem solving ability of the students of senior high school senior high school Kupang. (3) The developed physics SSP of PBL model in laboratory activity is effective to improve learning motivation of the students of SMA Giovani Kupang.

\section{AKNOWLEDGEMENT}

The authors would like to thank the Faculty of Education, the Unwira Academics Office and the PBL Course Coordinator to facilitate studies in terms of data search for analytical purposes. Our thanks are also extended to all PBL Facilitators and students who have participated in this research

\section{REFERENCES}

[1] Evans, A., Hawskley, F., Holland, M.R and Caillau, I. (2008). Improving subject knowledge and subject pedagogic knowledge in employment based secondary initial teacher training in England. Available from Sheffield Hallam University Research Archive (SHURA) at: http://shura.shu.ac.uk/187/

[2] Koehler, M.J., \& Mishra, P. (2009). What is technological pedagogical content knowledge? Contemporary Issues in Technology and Teacher Education, 9(1), 60-70.

[3] Shulman, L. S. (1986). Those who understand: Knowledge growth in teaching. Educational Researcher, 15(2), 4-14.

[4] Hung, W., Jonanssen, D.H., \& Liu. R. (2009). Problem-Based Learning. Available at www.aect.org/edtech/edition3/ER5849x_C038.fm.pdf

[5] Barrows, H. S. \& Tamblyn, R. M. (1980). Problem based learning: an approach to medical education. New York: Springer Verlag.

[6] Savin-Baden, M. (2000). Problem-based Learning in Higher Education: Untold Stories. Buckingham: Open University Press.

[7] Mayer, R.E. (2002). Rote Versus Meaningful Learning. Theory into practice, Volume 41, Number 4, Autumn 2002.

[8] Holyoak, K. J. (1995). An invitation to cognitive science: problem solving. ( $2^{\text {rd }} \mathrm{ed}$.). New York: The MIT Press.

[9] Kaymacki, S. (2012). A Review of Studies on Worksheets in Turkey. US-China Education Review A 1 (2012) 57-64, ISSN 1548-6613.

[10] Pintrich, P.R.,\& Schunk, D.H. (1996). Motivation in education: Theory, research and applications, Englewood Cliffs, NJ: Prentice-Hall.

[11] Dörnyei, Z. (2001). Teaching and researching motivation, Harlow: Pearson Education Limited. 
[12] Thiagarajan, S., Semmel, D.S \& Semmel, M.I (1974). Instructional Development for Training Theacher of exceptional Children. Minnesota: Indiana University.

[13] Lawshe, C. H. (1975). A Quantitative Approach to Content Validity. Personnel Psychology, (28), 563-575.
[14] Norman, G.R., \& Schmidt, H.G. (2000). Effectiveness of problem based learning curricula: Theory, practice and paper darts, Medical Education, 34 (2000), 721-728.

[15] Akınoğlu, Orhan \& Tandoğan, R.Ö. (2007). The effects of problembased active learning in science education on students' academic achievement, attitude and concept learning. Eurasia Journal of Mathematics, Science \& Technology Education, 3(1), 71-81. 